\title{
The Admission of Women into the Legal Profession: A guide to archival sources at IALS
}

\section{Author}

Elizabeth Dawson

Formerly Archivist, Institute of Advanced Legal Studies

\section{Abstract}

The article provides a brief guide to some potential archival sources at IALS for gender based research, focussing particularly on the admission of women to the legal profession after the first world war and beyond. Sources will include the records of legal education, academic and membership organisations and material relating to professional practice. The article also provides guidance to researchers on using the IALS Archive,

\section{Biographical summary}

Elizabeth Dawson was Archivist (part - time) at the Institute of Advanced Legal Studies from 2003 to 2014, where she developed archive collections and research facilities. She has extensive experience of Archives and Records Management, having worked at The Public Record Office (now the National Archives), The National Maritime Museum, The Inner London Education Authority and BP Exploration. She is an archive management consultant, specialising in the UK charitable, cultural \& heritage, educational, legal and public sectors, and she also mentors candidates studying for post graduate and professional archive qualifications.

Word count 2155 


\section{INTRODUCTION}

This article outlines some sources for the history of women in the legal profession from 1919 and beyond, held at The Institute for Advanced Legal Studies (IALS).

The IALS archive collections, which have been developed and expanded since their inception in 1997 now include the the Records of Legal Education archives, IALS institutional archives, the archives of law librarianship associations, and The Bar Council archives.

There are a number of potentially useful and relevant sources within these archive collections relating to the history of women in the legal profession, in particular the legal education and training of women; women in professional practice; women academics and women law librarians: these primary sources will be of use in tracing both the individual careers of women in the law, and also for the wider history of women in the legal profession.

An earlier article on sources for legal biography at IALS (see bibliography) gives further guidance on the archive material held at IALS, and readers should refer to it for detailed information on the collections and on additional sources for legal biography. The emphasis of this article is therefore on examples of what might be found within the records, and it is hoped that this will encourage further research, particularly in the Bar Council Archive, which has been recently catalogued and is as yet a relatively unexplored resource.

The main sources for women in legal education will be found in the extensive surviving archives of the Council of Legal Education (CLE) and in the series of Law Society examination results. It should be noted, however, that IALS holds only material relating to Law Society examinations: the remainder of the archive has been retained by the Society and can be seen by appointment at the Law Society Library.

\section{LEGAL EDUCATION AND TRAINING}

\section{THE COUNCIL OF LEGAL EDUCATION}

This extensive archive includes Minutes of the Council and Executive Committees, Regulations, Reports, Calendars and Bar Examination results. The main series of interest are likely to be:

\section{Bar Examination Results (series CLE 11)}

The passing of the Sex Disqualification (Removal) Act in 1919 meant that women could no longer be refused entry in to the legal profession and the first candidates for both the Bar and Law Society Examinations enrolled at the end of 1919. These included Helena Normanton, whose successful examination marks can be seen in the Bar Examination results for 1922 (ref CLE 11/11). The progress of many other candidates can be traced in this series of volumes, which give both individual subjects taken, marks for each examination, final overall grades and class of honours. Maximum and minimum totals for each subject are also given: this will enable researchers to place individual marks within a wider context. It is also interesting to note that the names of women candidates in many of the early volumes have been underlined in pencil: this may have been in order to produce statistics for The Council's annual reports.

\section{CLE Reports, Minutes, Regulations and Calendars}

As one might expect, The CLE Annual Reports (series CLE 14) make reference to the 1919 Act and the consequent admission of women. The report for 1920/21 (CLE 14 / 1), 
notes the passing of the Act and gives details of the number of women currently studying, although not their names, but noting no less than three first class passes in Constitutional Law, Criminal Law and Real Property \& Conveyancing. Volume CLE 14 / 2 also gives further information for 1921 / 22, noting that under current regulations, the earliest date at which women could be called to the bar would be Easter 1922. [see illustrations - CLE 14/1 and CLE 14 / 2 ].

The minutes of the Council (series CLE 2) are similarly neutral and factual, and give little idea of the actual discussion of what must have been regarded as a controversial subject. The Council Minutes of $22^{\text {nd }}$ November 1920 (ref CLE 2 / 10) make brief reference to the issue, but move rapidly on to other matters including the admission of Bombay Magistrates. However, this series, together with the Consolidated Regulations in series CLE 5 provides useful material in terms of the formal and regulatory framework and should not be overlooked. The printed Calendars (CLE 15), published annually from 1901 provide further summary information and include the names of some students, together with details of Consolidated Regulations, Rules for examinations of students, examination questions, lectures and classes, scholarships and prizes and pass certificates.

\section{THE LAW SOCIETY}

The Law Society Examination results also give a detailed account of women candidates and their achievements. There are several series of results for each level, (in series LSOC 2 - 14) giving subjects, marks obtained, minimum and maximum total marks, together with other details including home address and to whom articled. Volume LSOC 10 / 45 shows results for several women, including Carrie Morrison, the first woman solicitor, and Maud Crofts, who were amongst the first women to take Law Society exams. [see illustrations LSOC 10 / 45]

In addition to the examination results, researchers might usefully explore the series of question papers in series LSOC / 1 which in addition to providing details of the questions posed, also give an insight in to the contemporary legal and social context.

\section{PROFESSIONAL PRACTICE (THE BAR COUNCIL)}

The archives of The Bar Council were transferred to IALS in 2012 and have now been fully catalogued. Some volumes include subject indexes, but many do not and may require detailed examination in order to find relevant material. However, potential sources on the admission of women are likely to include the following series: Regulations and Bye-laws (BCO 2); Minutes of the Bar Council (BCO 4); AGM agendas (BCO 6); Executive Council Minutes (BCO 8); Special Committee minutes (BCO 13), Annual Statements (BCO 19), Out letter books (BCO 23) and Inns of Court Regulations (BCO 40).

A brief search in these records has provided some revealing insights into attitudes towards the admission of women into the legal profession. The minutes of the Bar Council note that on $17^{\text {th }}$ January 1913, at The Bar Council AGM, a positively worded proposal was made by Mr Holford Knight in favour of admitting women to the Bar. In spite of the Attorney General's comments that "no-one was apparently willing to speak against the motion", the meeting voted to oppose the motion, by "an overwhelming" (and presumably silent) majority. (BCO 4 / 24 p 24 - 25) [see illustration ]

The same volume also contains a letter from a Mr C W Wallen of Chicago, congratulating the Bar Association on their decision, on the grounds that " the woman's brain was never 
constructed for higher office than kitchen and family", and requesting that a copy of the decision be sent to the American Bar, in order to "strengthen our front against the woman nuisance". (BCO $4 / 14$ p 35) [see illustration ]. The minutes record merely that the letter was "read".

In contrast, the AGM of 1920, having perhaps bowed to the inevitable, briefly notes that women were now being admitted, before moving on to more pressing topics.

By 1922, faced with the real possibility of newly qualified women barristers appearing in court, a directive from the Royal Courts of Justice was issued, and a copy retained with the minutes of 1922 (BCO 4 / 17a) which sets out the Judges' requirements that women should wear Barristers wigs which should "completely cover and conceal the hair"; in addition dresses should be dark, high necked and "not shorter than their gowns"...[see illustration ]

\section{ACADEMICS}

The history of women Law Academics is an area of growing interest and research. IALS holds a number of archives of academic organisations in which women have played a prominent role, and in which evidence of the careers of women academics may therefore be traced.

The most extensive and comprehensive archive is that of the Society of Legal Scholars, whose history and development from 1909 - 2009 has been described in Professor Ray Cocks and Professor Fiona Cownie's informative centenary history, (see bibliography) . In addition to the formal records of the society (including AGMs (SPTL 4), Council \& Committee Minutes (SPTL 1), Conference Proceedings and Papers (SPTL 16) which may be useful for tracing the activities of individual members, the archive includes early membership lists \& registers (SPTL 6 \& 7), members directories and regulations (SPTL 14). The latter, ostensibly routine records complied as current information guides have nevertheless proved to be a fruitful source of information, as illustrated in Professor Cownie's short case study, which follows this article.

Other membership organisations in which Women academics have played a role are also represented in the IALS archives collection. These include The Association of Law Teachers (ALT), The Socio Legal Studies Association and The Society of Advanced Legal Scholars (SALS). These smaller collections also include membership directories, regulations, papers and minutes of meetings and will undoubtedly merit further exploration.

\section{LAW LIBRARIANS}

Women have also played a significant role in the development of Law Librarianship, and they continue to do so. The extent to which they were accepted as equal within the profession is a relatively unexplored area of research, and archival sources at IALS may provide a rich resource for further study.

The IALS institutional archive includes much material on the development of the library and the contribution of women in law librarianship and in addition to its own archive, IALS holds the archives of both The British and Irish Association of Law Librarians (BIALL) and the International Association of Law Libraries (IALL).

Notable women Law Librarians include Muriel Anderson (d 2006), formerly Librarian at 
IALS and Betty Moys, both innovators in their fields.

Muriel Anderson's professional activities and achievements can be traced within the IALS Archives, in particular in IALS / $09 / 1-3$ ) and also in the archives of The International Association of Law Librarians (IALL) and The British \& Irish Association of Law Librarians (BIALL), both of whose archives are held at IALS. Further biographical information can be found at http://ials.sas.ac.uk/about//ALS History Muriel Anderson.htm

Betty Moys (1928 - 2002) also played a significant role in the development of both IALS and Law Librarianship, and her papers relating to the development of a specialist law classification scheme can be found in her papers (MOYS / $1-3$ ). Further evidence of her professional activities may also be traced within the IALS Archives and in the records of IALL and BIALL.

For further biographical information, see http://www.aallnet.org/mm/Publications/lli/LLJArchives/Vol-94/pub Ilj v94n03/2002-34.pdf

\section{USING THE IALS ARCHIVE}

The archive at IALS is open to all researchers and there is no charge for access. Access is by advance appointment only (email: ials@sas.ac.uk or telephone 0207862 5790).

Catalogues are available on the IALS website and it is strongly recommended that researchers should familiarise themselves with the scope and contents of the collections in advance (for further details see http://ials.sas.ac.uk/library/archives/archive.htm ). Most material is open, but where confidentiality and access restrictions are in place, these are noted in the catalogue.

Guidance notes and regulations for users can be found on the IALS website http://ials.sas.ac.uk/library/archives/docs/Archives_at_IALS_Regulations_for_use_of_Archi ves.pdf . Laptops may be used, and digital non flash photography may be permitted under supervision (subject to copyright regulations).

For further information about research in the IALS archives, see Archival Sources for Legal Biography at the Institute of Advanced Legal Studies) below.

\section{PUBLISHED WORKS CONSULTED AND FURTHER READING}

The following works were consulted when preparing this article:

- Fiona Cownie \& Ray Cocks: A Great and Noble Profession (Hart, 2009)

- Patrick Polden: Portia's Progress: Women at the Bar in England, 1919 - 1939 (International Journal of the Legal Profession, 12:3 293-338)

- See also: Elizabeth Dawson: Archival Sources for Legal Biography at the Institute of Advanced Legal Studies. Legal Information Management Vol 14, number 1, 2014.

\section{HYPERLINK}

"http://sas- 